\title{
Wildlife Habitat on Grazed or Ungrazed Small Pond Shorelines in South Texas
}

\author{
RICHARD J. WHYTE AND BRIAN W. CAIN
}

\begin{abstract}
Three man-made ponds constructed in 1956 and fenced to exclude cattle from the shoreline were selected to study the effects of cattle on shoreline vegetation. These ponds were partially opened in 1977 to allow grazing on one-half of the shoreline. The vegetation was sampled monthly with an inclined 10-point frame placed at 1-m intervals along transects in the opened and fenced sections of the shorelines. In most areas the foliar cover and vegetation height were reduced by cattle pressure. The stable Longtom Community and the Knotgrass-Smartweed Community were more affected by cattle pressure than the Transition Community which changed as the water level rose or dropped. The seasonal Aquatic Community was least affected by cattle pressure and thus maintained good stands of waterfowl food plants. Carefully planned grazing which allows key rest and grazing periods will control the impact of grazing on the shoreline vegetation. Stable waterfowl habitat on the shorelines of small man-made ponds in South Texas can best be protected by fencing at least one-half of the shoreline to restrict cattle use.
\end{abstract}

Grazing may be a useful practice for waterfowl habitat management in that landowners may modify habitat by regulating cattle grazing. Plant succession in a marsh or within a shoreline community can be maintained by grazing management at a seral stage most useful to waterfowl (Singleton 1965, Chabreck 1968). Although the effects of grazing on marsh communities (Chabreck 1968, Valentine 1969) and lake shorelines (Hoffman and Stanley 1978) have been reported, the detailed effects of grazing on the shoreline vegetation of small ponds within pastures specifically for cattle production have not been adequately documented.

Grazing directly affects shoreline vegetation by reducing its height (Bue et al. 1952, Berg 1956, Gjersing 1975), phytomass (Hoffmann and Stanley 1978), density (Chabreck 1968), and botanical composition (Gjersing 1975, Hoffman and Stanley 1978). Bue et al. (1952) reported that a stocking rate of $10.8 \mathrm{ha} / \mathrm{AU}$ allowed development of a grass shoreline and stocking rates higher

Authors are graduate student, Department of Wildlife and Fisheries Science, Texas A\&M University, College Station, Texas 77843; and research biologist, Patuxent Wildlife Research Center, Laurel, Maryland 20811.

This report is Welder Wildlife Contribution No. 248. The study received financial support from the Rob an Bessie Welder Wildlife Foundation, Sinton, Texas. Drs. Eric G. Bolen and .J. Scifres provided editorial assistance and an anonymous reviewer for this journal provided excellent suggestions. Patty McDonald and Becky Wieland typed the manuscript.

Manuscript received July 13, 1979. than 6 to $7 \mathrm{ha} / \mathrm{AU}$ eliminated the vegetation and left bare shoreline. Stocking rates of 0.8 to $1.2 \mathrm{ha} / \mathrm{AU}$ and lower from May to November allowed development of a grassy shoreline on stock ponds in western North Dakota (Lokemoen (1973).

Grazing by livestock can restore habitat previously unusable by waterfowl. Removal of dense cattail (Typha latifolia) by cattle from the shorelines of prairie potholes increased mallard (Anas platyrhynchos) and lesser scaup (Aythya affinis) production (Keith 1961). However, Kirsch (1961) viewed any form of grazing on shoreline vegetation as harmful to waterfowl production. Pair numbers, nesting densities, and nest success of nesting waterfowl in North Dakota on stock ponds werc reduced when grazing was permitted in his 4-year study. Grazing management may be a valuable tool in waterfowl habitat management; but where stocking rates are high, partial fencing of ponds may be required to prevent total destruction of the shoreline vegetation (Hamor et al. 1968). Lighter stocking rates and rest-rotation grazing systems may also allow maintenace of adequate shoreline vegetation to provide productive wildlife habitat (Gjersing 1975, Mundinger 1976). The objective of this study was to evaluate the effects of cattle grazing on the shoreline vegetation of small man-made ponds on the Coastal Prairie of Texas.

\section{Study Area}

Three man-made impoundments on the Rob and Bessie Welder Wildlife Refuge near Sinton, Texas, were selected for study. Each impoundment, locally referred to as "tanks," was constructed in 1956 and fenced to exclude cattle in 1957. Two of the tanks have since expanded beyond their original fences so that sections of the shorelines have had a history of grazing. The third tank did not expand beyond the fence so half the shoreline was opened to cattle in July 1977.

The tanks were situated in clay soils (Drawe et al. 1978) within a 4-pasture, deferred-rotation grazing system. The characteristics of each tank were:

1. Large Lowland-Paspalum ( $L L P)$ Tank. Situated in a paspalum (Paspalum lividum) community in a pasture that was stocked at 3.6 to $2.8 \mathrm{ha} / \mathrm{AUM}$ throughout the study, this tank was rested for 120 days from late summer (July 25) to mid-fall (November 22). Cattle use was 3.7 to $3.9 \mathrm{~m}$ shoreline/AU throughout the study. Ratio of ungrazed to grazed shoreline was 80 percent on this 1.74 ha tank. 
2. Large Upland Chaparral-Mixed Grass (LUC) Tank. This tank was 1.02 ha surface area and situated in a blackbrush acacia (Acacia rigidula)/silver bluestem (Bothriochloa saccharoides Swartz var. longipaniculata Gould) community in a pasture that was stocked at 3.4 to 4.2 ha/ AUM throughout the study. A rest period extended for 42 days in the summer (June 13 to July 25). Animal pressure was 2.99 to $3.99 \mathrm{~m}$ shoreline/AU throughout the study and 50 percent of the shoreline was grazed on this tank

3. Small Upland Chaparral-Mixed Grass (SUC) Tank. This tank was situated in the same rangeland community and pasture as the previous tank. However, the animal pressure was 0.69 to $0.83 \mathrm{~m}$ shoreline/AU throughout the study and about 70 percent of the shoreline was grazed. This was the smallest tank $(0.34$ ha surface area) studied, and consequently, the shoreline was grazed at four times the pressure of the larger tanks because the stocking rate was similar throughout the pasture.

\section{Methods}

The impoundments were partially fenced to allow direct comparison of grazed with ungrazed shoreline at each site. The shoreline vegetation, categorized as grasses, forbs, moist soil plants (i.e., sedges and rushes), emergent or submersed aquatic plants, was sampled monthly from June 1977 to May 1978. Ten permanent transects were randomly located on each of the ungrazed and grazed shorelines of the larger tanks; five transects were established on the smaller tank. In June 1977 permanent pegs were placed at $10-\mathrm{m}$ intervals along these transects on the shore and into the ponds until a depth of $60 \mathrm{~cm}$ was reached. The lengths of individual transects varied with water depth throughout the study, always extending from the permanent peg to a water depth of $60 \mathrm{~cm}$ (Robel 1961).

The shoreline vegetation was sampled monthly with an inclined 10-point frame placed at 1-m intervals along each transect (Jolly 1954). Foliar cover and plant heights were recorded for each species. Standing crop was harvested on a bi-monthly basis from $0.1 \mathrm{~m}$ rectangular plots randomly placed near the permanent pegs along two transects on each of the ungrazed and grazed shorelines for each tank. The standing vegetation was clipped to a $1-\mathrm{cm}$ stubble height, oven-dried at $36^{\circ} \mathrm{C}$ fo 144 hours and weighed. Grasses were identified according to Gould and Box (1965) and all other plant species according to Jones (1975).

Analysis of variance and Duncan's multiple range test (Steele and Torrie 1960) were used to test the effects $(P=0.05)$ of grazing on plant height, standing crop and density by season for each tank.

Table 1. Foliar cover (\%) of aquatic plants of shoreline zones at LLP, LUC, and SUC tanks in relation to season and grazing, June 1977-May 1978.

\begin{tabular}{|c|c|c|c|c|c|c|}
\hline \multirow{2}{*}{$\begin{array}{l}\text { Tank } \\
\text { Community }\end{array}$} & \multicolumn{2}{|c|}{ Summer } & \multicolumn{2}{|c|}{ Fall-winter } & \multicolumn{2}{|c|}{ Spring } \\
\hline & $\overline{\mathrm{UG}^{1}}$ & G & $\mathrm{UG}$ & G & $\overline{\mathrm{UG}}$ & G \\
\hline $\begin{array}{l}\text { LLP } \\
\text { Longtom } \\
\text { Knotgrass-S1 } \\
\text { Transition } \\
\text { Aquatic }\end{array}$ & $\begin{array}{r}t_{b} \\
5_{a} \\
0_{a} \\
82_{a}\end{array}$ & $\begin{array}{r}0_{\mathrm{b}} \\
2 \mathrm{~b}_{\mathrm{b}} \\
0_{\mathrm{a}} \\
75_{\mathrm{a}}\end{array}$ & $\begin{array}{r}0_{\mathrm{b}} \\
0_{\mathrm{c}} \\
0_{\mathrm{a}} \\
43_{\mathrm{b}}\end{array}$ & $\begin{array}{r}0_{\mathrm{b}} \\
0_{\mathrm{c}} \\
0_{\mathrm{a}} \\
39_{\mathrm{b}}\end{array}$ & $\begin{array}{l}0_{\mathrm{b}} \\
0_{\mathrm{c}} \\
0_{\mathrm{a}} \\
2_{\mathrm{c}}\end{array}$ & $\begin{array}{l}0_{\mathrm{b}} \\
0_{\mathrm{c}} \\
0_{\mathrm{a}} \\
4_{\mathrm{c}}\end{array}$ \\
\hline $\begin{array}{l}\text { LUC } \\
\text { Longtom } \\
\text { Knotgrass-S } \\
\text { Transition } \\
\text { Aquatic }\end{array}$ & $\begin{array}{r}3 \mathrm{a} \\
20_{\mathrm{a}} \\
0_{\mathrm{b}} \\
72_{\mathrm{a}}\end{array}$ & $\begin{array}{r}T_{b} \\
3 b \\
3 a_{a} \\
61_{a}\end{array}$ & $\begin{array}{c}0_{\mathrm{b}} \\
0_{\mathrm{c}} \\
\mathrm{T}_{\mathrm{b}} \\
22_{\mathrm{b}}\end{array}$ & $\begin{array}{r}0_{\mathrm{b}} \\
\mathrm{T}_{\mathrm{c}} \\
\mathrm{T}_{\mathrm{b}} \\
2 \mathrm{l}_{\mathrm{b}}\end{array}$ & $\begin{array}{l}0_{\mathrm{b}} \\
0_{\mathrm{c}} \\
0_{\mathrm{b}} \\
\mathrm{T}_{\mathrm{c}}\end{array}$ & $\begin{array}{l}0_{\mathrm{b}} \\
0_{\mathrm{c}} \\
0_{\mathrm{b}} \\
\mathrm{T}_{\mathrm{c}}\end{array}$ \\
\hline $\begin{array}{l}\text { SUC } \\
\text { Longtom } \\
\text { Transition } \\
\text { Aquatic }\end{array}$ & $\begin{array}{r}5 \mathrm{a} \\
0_{\mathrm{a}} \\
87_{\mathrm{a}}\end{array}$ & $\begin{array}{r}0_{\mathrm{b}} \\
0_{\mathrm{a}} \\
75_{\mathrm{a}}\end{array}$ & $\begin{array}{r}0_{\mathrm{b}} \\
0_{\mathrm{a}} \\
25_{\mathrm{b}}\end{array}$ & $\begin{array}{r}0_{\mathrm{b}} \\
0_{\mathrm{a}} \\
15_{\mathrm{a}}\end{array}$ & $\begin{array}{r}0_{b} \\
0_{a} \\
29_{b}\end{array}$ & $\begin{array}{r}0_{\mathrm{b}} \\
0_{\mathrm{a}} \\
26_{\mathrm{b}}\end{array}$ \\
\hline
\end{tabular}

Means within a row followed by the same letter are not significantly $(P>0.05)$ diferent.

IUG $=$ ungrazed, $\mathrm{G}=$ grazed, $\mathrm{S}=$ smartweed, $\mathrm{T}=$ traice $(<1.0 \%)$

\section{Results and Discussion}

Drawe et al. (1978) described generalized vegetation communities for the ponds and lakes of the Welder Wildlife Refuge. Shoreline communities were ordered based on the soil moisturc regime.

\section{Aquatic Community}

Cattle entering the water did not affect the percentage foliar cover of the submersed vegetation during any season, regardless of tank (Table 1). Cattle had no effect on the height of aquatic emergent vegetation at the LUC tank but there was a decrease during the summer at the LLP and SUC tanks (Table 2).

Table 2. Height (cm) of vegetation of the shoreline zones at LLP, LUC, and SUC tanks in relation to season and grazing, June 1977-May 1978.

\begin{tabular}{|c|c|c|c|c|c|c|}
\hline \multirow{2}{*}{$\begin{array}{l}\text { Tank } \\
\text { Community }\end{array}$} & \multicolumn{2}{|c|}{ Summer } & \multicolumn{2}{|c|}{ Fall-winter } & \multicolumn{2}{|c|}{ Spring } \\
\hline & $\overline{\mathrm{UG}^{\prime}}$ & $\mathrm{G}$ & $\overline{\mathrm{UG}}$ & $G$ & UG & $G$ \\
\hline $\begin{array}{l}\text { LLP } \\
\quad \text { Longtom } \\
\text { Knotgrass-S' } \\
\text { Transition } \\
\text { Aquatic }\end{array}$ & $\begin{array}{r}63_{\mathrm{a}} \\
56_{\mathrm{a}} \\
37_{\mathrm{a}} \\
8_{\mathrm{a}}\end{array}$ & $\begin{array}{c}39_{\mathrm{d}} \\
39_{\mathrm{b}} \\
19_{\mathrm{bc}} \\
4 \mathrm{~b}\end{array}$ & $\begin{array}{l}57_{\mathrm{b}} \\
55_{\mathrm{a}} \\
29_{\mathrm{ab}} \\
22_{\mathrm{bc}}\end{array}$ & $\begin{array}{r}49_{\mathrm{c}} \\
39_{\mathrm{b}} \\
24_{\mathrm{ab}} \\
2 \mathrm{bc}\end{array}$ & $\begin{array}{r}5 l_{\mathrm{c}} \\
38_{\mathrm{b}} \\
17_{\mathrm{c}} \\
\mathrm{l}_{\mathrm{c}}\end{array}$ & $\begin{array}{r}31_{e} \\
20_{c} \\
12_{c} \\
1_{c}\end{array}$ \\
\hline $\begin{array}{l}\text { LUC } \\
\text { Longtom } \\
\text { Knotgrass-S } \\
\text { Transition } \\
\text { Aquatic }\end{array}$ & $\begin{array}{r}54_{a} \\
30_{a} \\
24_{a} \\
7 a\end{array}$ & $\begin{array}{r}48_{\mathrm{b}} \\
25_{\mathrm{b}} \\
16_{\mathrm{b}} \\
8 \mathrm{a}\end{array}$ & $\begin{array}{c}57_{\mathrm{a}} \\
31_{\mathrm{a}} \\
14_{\mathrm{bc}} \\
22_{\mathrm{b}}\end{array}$ & $\begin{array}{r}35_{\mathrm{c}} \\
14_{\mathrm{c}} \\
9_{\mathrm{de}} \\
0_{\mathrm{bc}}\end{array}$ & $\begin{array}{l}50_{\mathrm{b}} \\
28_{\mathrm{ab}} \\
12_{\mathrm{cd}} \\
0_{\mathrm{bc}}\end{array}$ & $\begin{array}{r}30_{\mathrm{d}} \\
12_{\mathrm{c}} \\
7_{\mathrm{e}} \\
0_{\mathrm{bc}}\end{array}$ \\
\hline $\begin{array}{l}\text { SUC } \\
\text { Longtom } \\
\text { Transition } \\
\text { Aquatic }\end{array}$ & $\begin{array}{r}71_{\mathrm{a}} \\
46_{\mathrm{a}} \\
8 \\
8_{\mathrm{a}}\end{array}$ & $\begin{array}{c}41_{\text {bcd }} \\
21_{a b} \\
0,\end{array}$ & $\begin{array}{c}54_{\mathrm{b}} \\
29_{\mathrm{ab}} \\
0_{\mathrm{b}}\end{array}$ & $\begin{array}{c}3{ }_{d} \\
25_{a b} \\
0 b\end{array}$ & $\begin{array}{c}52_{\mathrm{bc}} \\
29_{\mathrm{ab}} \\
0_{\mathrm{b}}\end{array}$ & $\begin{array}{c}24_{\mathrm{cd}} \\
10_{\mathrm{b}} \\
0_{\mathrm{b}}\end{array}$ \\
\hline
\end{tabular}

Means within a row followed by the same letter are not significantly $(P>0.05)$ different.

'Same as Table 1

The Aquatic Community of the tanks were typified by submersed plants with frequent emergent. The LLP and LUC tanks supported areas covered by algae, water primrose (Ludwigia peploides), southern naiad (Naias guadalupensis), duckweed (Lemna minor), and waterlily (Nymphaea elegans). The Aquatic Community of the SUC tank was characterized by muskgrass (Chara spp.), southern naiad, algae, and duckweed.

Overall, the disturbances of the Aquatic Community from upland vegetation, typically evolved with a drop in water level. The water level usually receded most dramatically in the summer. Cattle did not affect the percentage foliar cover of the vegetation in the Transition Community at the LLP and LUC tanks where present (Table 3 ). The percentage foliar cover of the vegetation was

Table 3. Foliar cover (\%) of vegetation of shoreline zones at LLP, LUC, and SUC tanks in relation to season and grazing, June 1977-May 1978.

\begin{tabular}{|c|c|c|c|c|c|c|}
\hline \multirow{2}{*}{$\begin{array}{l}\text { Tank } \\
\text { Community }\end{array}$} & \multicolumn{2}{|c|}{ Summer } & \multicolumn{2}{|c|}{ Fall-winter } & \multicolumn{2}{|c|}{ Spring } \\
\hline & UG' & G & UG & G & UG & $G$ \\
\hline \multicolumn{7}{|l|}{ LLP } \\
\hline Longtom & $90_{c}$ & $77_{\mathrm{d}}$ & $97 \mathrm{a}$ & $90_{b c}$ & $95_{b}$ & $62_{e}$ \\
\hline Knotgrass-S ${ }^{2}$ & $84_{a}$ & $79_{\mathrm{b}}$ & $90 \mathrm{a}$ & $74 b$ & $74_{b}$ & $36_{c}$ \\
\hline Transition & $85_{a}$ & $49 \mathrm{bc}$ & $55_{\mathrm{bc}}$ & $59 \mathrm{~b}$ & $49_{\mathrm{bc}}$ & $42_{c}$ \\
\hline Aquatic & $82_{a}$ & $75_{a}$ & $43_{b}$ & $39_{b}$ & $2 \mathrm{c}$ & $4_{c}$ \\
\hline \multicolumn{7}{|l|}{ LUC } \\
\hline Longtom & $92_{b}$ & $82_{c}$ & 97, & $75_{d}$ & $95_{a}$ & $60_{e}$ \\
\hline Knotgrass-S & $70_{c}$ & $64_{c}$ & $93 \mathrm{a}$ & $57_{d}$ & $82_{b}$ & $53_{d}$ \\
\hline Transition & $49_{\mathrm{ab}}$ & $37_{\mathrm{ab}}$ & $41_{\mathrm{ab}}$ & $50_{a}$ & $34_{b}$ & $38_{\mathrm{at}}$ \\
\hline Aquatic & $72_{a}$ & $61_{a}$ & $22_{b}$ & $21_{b}$ & $\mathrm{~T}_{\mathrm{c}}$ & $0_{c}$ \\
\hline \multicolumn{7}{|l|}{ SUC } \\
\hline Longtom & 78 & $65_{b}$ & $80_{\mathrm{a}}$ & $56_{b}$ & $75_{a}$ & $59 \mathrm{~b}$ \\
\hline Transition & $56_{a}$ & $10_{\mathrm{a}}$ & $58_{\mathrm{b}}$ & $23_{b}$ & $50 \mathrm{a}$ & $14_{b}$ \\
\hline Aquatic & $87 a$ & $75_{a}$ & $25_{b}$ & $15_{b}$ & $29_{b}$ & $26_{b}$ \\
\hline
\end{tabular}

Means within a row followed by the same letter are not significantly $(P>0.05)$ diferent.

'Same as Table 1. 
reduced by cattle during all seasons on the SUC tank. Height of the vegetation declined with grazing on all tanks (Table 2).

The effects of grazing on the vegetation of the Transition Community were variable, being far more severe on the SUC tank than on the LLP and LUC tanks. It is vital that vegetation become established once the water level recedes, first to prevent soil and nutrient loss by wind erosion of the drying soil, and second to provide mulch and nutrients for pond system once the zone refloods.

The Transition Community of all tanks was invaded by aggressive pioneer plant species which were capable of withstanding a disturbance such as grazing. Pioneer species occupying the Transition Community at the LLP tank were forbs including nama (Nama stenocarpum), heliotrope (Heliotropium procumbens), yellow-cress (Rorippa teres); and grasses, such as common Bermudagrass (Cynodon dactylon), teal lovegrass (Eragrostis hypnoides), and barnyardgrass (Echinochloa crusgalli). The Transition Community of the LUC tank was invaded by nama, bladderpod (Lesquerella lindheimeri), peppergrass(Lepidium lasiocarpum), common Bermudagrass, and teal lovegrass. Forbs such as nama, yellow-cress, and frogfruit (Phyla incisa), and grasses such as teal lovegrass and common Bermudagrass combined with some moist-soil plants, i.e. spike rush (Eleocharis macrostachya) and cattail(T. domingensis) to dominate the Transition of the SUC tank.

The Transition Community provides food plants such as barnyardgrass, common Bermudagrass, and teal lovegrass, which becomes available to ducks once the zone refloods. Furthermore, American wigeon (Anas americana) were often observed grazing in the Transition Community of the LLP and LUC tanks in the late winter. Bolen and Forsyth (1967) reported common Bermudagrass to be a major item in the summer diet of the black-bellied whistling duck (Dendrocygna autumnalis) on the Coastal Prairie of Texas.

\section{Knotgrass-Smartweed Community}

The Knotgrass-Smartweed Community was dominated by knotgrass (Paspalum distichum) and smartweed (Persicaria hyderopiperoides) on extremely moist to flooded soils. Moist soil plants such as sedge (Cyperus digitatus), spikerush, cattail, bullrush (Scirpus californicua), and arrowhead (Sagittaria longiloba) were of secondary importance.

Total percentage foliar cover of the vegetation (Table 3) and moist-soil plants (Table 4) were reduced by cattle at the LUC and the LLP tank (Fig. 1). Height of the vegetation was reduced by cattle at both tanks (Table 2).

The Knotgrass-Smartweed Community is of tremendous value to some wildlife species. The emergent vegetation provided nesting habitat for many marshbirds, including American coots (Fulica americana), common gallinules (Gallinula chloropus) and purple gallinules (Porphyrula martinica). Of six nests located in the Knotgrass-Smartweed Community at LLP and LUC tanks in the breeding seasons of 1977 and 1978, five nests were established on the ungrazed plots. Furthermore, several widely used duck food plants including smartweed thrived on this zone. Consequently, disturbances due to foraging and trampling by cattle may reduce nesting success or density of waterfowl in this community on man-made stock ponds.

\section{Longtom Community}

The Longtom Community was dominated by longtom (Paspalum lividum) and indicated the first shoreline zone typical of the moist soils surrounding the tanks. Longtom occupies moist soils too dry for sedges and too wet for common Bermudagrass (Scifres and Mutz 1975).

Grazing reduced the percentage foliar cover of vegetation of the Longtom Community on all tanks (Table 3). The percentage foliar cover of moist-soil plants (Carex brittoniana, and Cyperus articulatus) declined with grazing at all tanks (Table 4). Vegetation height (Table 2) was reduced by grazing regardless of tank.

Foliar cover of grasses in the Longtom Community was com-
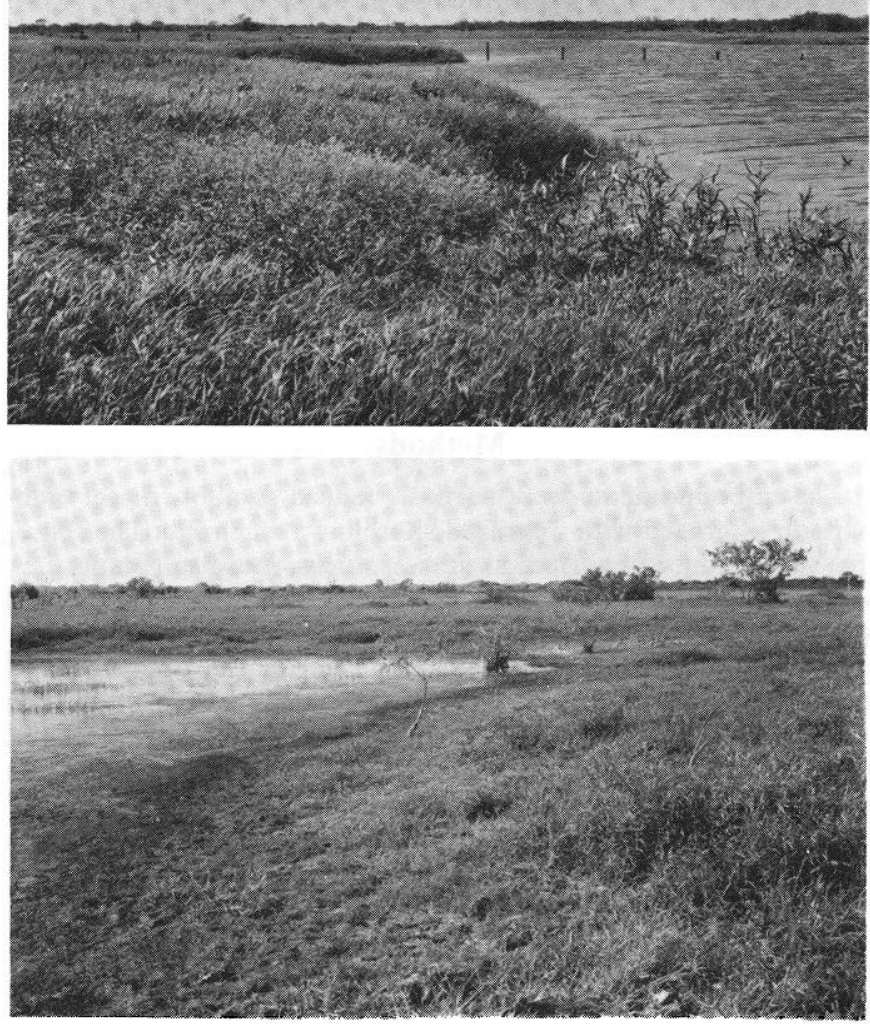

Fig. 1. Knotgrass-Smartweed Zone of the large lowland-paspalum (LLP) tank. (a) Dense stand of knotgrass and smartweed on the ungrazed section, and (b) reduced foliar cover on the grazed section.

posed almost entirely of longtom, with common Bermudagrass being of minor importance. Percentage foliar cover of grasses at the LLP and LUC tanks was not reduced by grazing in the summer. However, cattle reduced the percentage foliar cover of grasses in the spring at both tanks, and during the fall and winter at the LUC tank (Table 5). Cattle were removed from the pasture containing the LLP tank during 120 days of the summer and fall, which may explain why the percentage foliar cover of grasses was not signifi-

Table 4. Foliar cover (\%) of moist soil plants of shoreline zones at LLP, LUC, and SUC tanks in relation to season and grazing, June 1977-May 1978.

\begin{tabular}{|c|c|c|c|c|c|c|}
\hline \multirow{2}{*}{$\begin{array}{l}\text { Tank } \\
\text { Community }\end{array}$} & \multicolumn{2}{|c|}{ Summer } & \multicolumn{2}{|c|}{ Fall-winter } & \multicolumn{2}{|c|}{ Spring } \\
\hline & $\mathrm{UG}^{1}$ & G & $\overline{\mathrm{UG}}$ & G & $\overline{\mathrm{UG}}$ & $\mathrm{G}$ \\
\hline \multicolumn{7}{|l|}{ LLP } \\
\hline Longtom & $19_{a}$ & $9_{b}$ & $2 \mathrm{c}$ & $T_{d}$ & $3 \mathrm{c}$ & $\mathrm{T}_{\mathrm{d}}$ \\
\hline Knotgrass-S 1 & $45_{a}$ & $39 a$ & $23_{b}$ & $9 \mathrm{c}$ & $5 \mathrm{c}$ & $3 \mathrm{c}$ \\
\hline Transition & $38 a$ & $2 \mathrm{c}$ & $13 \mathrm{~b}$ & $\mathrm{~T}_{\mathrm{c}}$ & $3 \mathrm{c}$ & $\mathrm{T}_{\mathrm{c}}$ \\
\hline Aquatic & $6 a$ & $1_{b}$ & $\mathrm{~T}_{\mathrm{c}}$ & $\mathrm{T}_{\mathrm{c}}$ & $0_{\mathrm{c}}$ & $0_{c}$ \\
\hline \multicolumn{7}{|l|}{ LUC } \\
\hline Longtom & $6 a$ & $2 \mathrm{~b}$ & $\mathrm{~T}_{\mathrm{b}}$ & $\mathrm{T}_{\mathrm{b}}$ & $\mathrm{T}_{\mathrm{b}}$ & $\mathrm{T}_{\mathrm{b}}$ \\
\hline Knotgrass-S & $11_{\mathrm{a}}$ & $2 c$ & $3 \mathrm{~b}$ & $T_{d}$ & $9 a$ & $\mathrm{~T}_{\mathrm{cd}}$ \\
\hline Transition & $7_{\mathrm{ab}}$ & $\mathrm{T}_{\mathrm{c}}$ & $4 b$ & $\mathrm{~T}_{\mathrm{c}}$ & $6 a$ & $\mathrm{~T}_{\mathrm{c}}$ \\
\hline Aquatic & $1_{a}$ & $\mathrm{~T}_{\mathrm{b}}$ & $\mathrm{T}_{\mathrm{b}}$ & $0_{\mathrm{b}}$ & $0_{\mathrm{b}}$ & $0_{\mathrm{b}}$ \\
\hline \multicolumn{7}{|l|}{ SUC } \\
\hline Longtom & $22_{a}$ & $5 \mathrm{bc}$ & $10_{\mathrm{b}}$ & $0_{\mathrm{c}}$ & $66_{b c}$ & $1_{c}$ \\
\hline Transition & $2 a$ & $0 \mathrm{a}$ & $1_{\mathrm{a}}$ & $4 a$ & $2 \mathrm{a}$ & $5 a$ \\
\hline Aquatic & $1_{a}$ & $0 \mathrm{a}$ & $0_{\mathrm{a}}$ & $0 a$ & $0_{\mathrm{a}}$ & $0_{\mathrm{a}}$ \\
\hline
\end{tabular}

Means within a row followed by the same letter are not significantly $(P>0.05)$ different.

'Same as Table 1. 
Table 5. Foliar cover (\%) of grasses of shorelines at LLP, LUC, and SUC tanks in relation to season and grazing, June 1977-May 1978.

\begin{tabular}{|c|c|c|c|c|c|c|}
\hline \multirow{2}{*}{$\begin{array}{c}\text { Tank } \\
\text { Zone } \\
\end{array}$} & \multicolumn{2}{|c|}{ Summer } & \multicolumn{2}{|c|}{ Fall-winter } & \multicolumn{2}{|c|}{ Spring } \\
\hline & $\mathrm{UG}^{1}$ & G & UG & G & UG & $\mathrm{G}$ \\
\hline $\begin{array}{l}\text { LLP } \\
\text { Longtom } \\
\text { Knotgrass-S' } \\
\text { Transition }\end{array}$ & $\begin{array}{l}69_{\mathrm{c}} \\
34_{\mathrm{b}} \\
47_{\mathrm{ab}}\end{array}$ & $\begin{array}{l}68_{c d} \\
38_{b} \\
39_{b}\end{array}$ & $\begin{array}{l}95_{\mathrm{a}} \\
67_{\mathrm{a}} \\
40_{\mathrm{ab}}\end{array}$ & $\begin{array}{l}90_{\mathrm{ab}} \\
62_{\mathrm{a}} \\
51_{\mathrm{a}}\end{array}$ & $\begin{array}{l}87_{\mathrm{b}} \\
66_{\mathrm{a}} \\
35_{\mathrm{b}}\end{array}$ & $\begin{array}{l}61_{c} \\
31_{b} \\
39_{b}\end{array}$ \\
\hline Aquatic & $2 \mathrm{a}$ & $2 \mathrm{a}$ & $\mathrm{T}_{\mathrm{b}}$ & $2_{\mathrm{ab}}$ & $T_{b}$ & $0_{b}$ \\
\hline $\begin{array}{l}\text { LUC } \\
\text { Longtom } \\
\text { Knotgrass-S } \\
\text { Transition } \\
\text { Aquatic }\end{array}$ & $\begin{array}{c}83_{\mathrm{b}} \\
37_{\mathrm{d}} \\
42_{\mathrm{ab}} \\
5 \mathrm{~b}\end{array}$ & $\begin{array}{l}79_{\mathrm{bc}} \\
59_{\mathrm{c}} \\
34_{\mathrm{ab}} \\
13_{\mathrm{a}}\end{array}$ & $\begin{array}{r}97_{\mathrm{a}} \\
81_{\mathrm{a}} \\
33_{\mathrm{b}} \\
1_{\mathrm{c}}\end{array}$ & $\begin{array}{r}75_{\mathrm{c}} \\
54_{\mathrm{c}} \\
47_{\mathrm{a}} \\
\mathrm{T}_{\mathrm{c}}\end{array}$ & $\begin{array}{r}95_{\mathrm{a}} \\
71_{\mathrm{b}} \\
20_{\mathrm{a}} \\
\mathrm{T}_{\mathrm{c}}\end{array}$ & $\begin{array}{r}58_{d} \\
38_{d} \\
30_{b} \\
0_{c}\end{array}$ \\
\hline $\begin{array}{l}\text { SUC } \\
\text { Longtom } \\
\text { Transition } \\
\text { Aquatic }\end{array}$ & $\begin{array}{r}46_{b} \\
53_{a} \\
4 a\end{array}$ & $\begin{array}{c}59_{\mathrm{ab}} \\
10_{\mathrm{b}} \\
0_{\mathrm{b}}\end{array}$ & $\begin{array}{r}67_{\mathrm{a}} \\
46_{\mathrm{a}} \\
0_{\mathrm{b}}\end{array}$ & $\begin{array}{c}55_{\mathrm{ab}} \\
17_{\mathrm{h}} \\
\mathrm{T}_{\mathrm{b}}\end{array}$ & $\begin{array}{r}61_{\mathrm{ab}} \\
44_{\mathrm{a}} \\
0_{\mathrm{b}}\end{array}$ & $\begin{array}{c}54_{\mathrm{ab}} \\
8_{\mathrm{b}} \\
0_{\mathrm{b}}\end{array}$ \\
\hline
\end{tabular}

Means within a row followed by the same letter are not significantly $(P>0.05)$ dif ferent.

'Same as Table 1

cantly reduced on the Longtom Community of the LLP tank during these seasons. However, cattle did graze heavily on longtom during the fall-winter and spring on the LUC tank. This agrees with the study of Durham and Kothmann (1977) who reported longtom to be intensively grazed by cattle from December to February on the Texas Coastal Prairie.

Longtom is a food item for cattle, and it also stabilizes the shoreline vegetation around small ponds in south Texas. Livestock disturbances that eliminate the Longtom Community may prove harmful to the pond in terms of wildlife habitat.

The role of tanks in wintering waterfowl management in south Texas is of increasing importance. Alternative water bodies supporting wintering waterfowl will be sought as industry and agriculture shrink the Texas coastal marshes (Singleton 1965). The Soil Conservation Service (USDA) has constructed many farm ponds in south Texas since the 1940's (SCS 1973, unpublished data). For example, there are 132 ponds in San Patricio County, 60 ponds in Refugio County and, 320 ponds in Bee County which have been constructed since the 1940 's. Some ponds range up to 40 ha in surface area; however, most are less than 0.8 ha. Blue-winged teals (Anas discors), green-winged teals (A. crecca), lesser scaups and wigeons, commonly wintering on the three study tanks, would benefit from an increase in small ponds in south Texas. Furthermore, the black-bellied whistling duck, a common breeding resident in south Texas (Bolen 1967), would also benefit by an increase in water bodies on which to raise broods. Proper management would benefit the shoreline vegetation on these ponds.

\section{Conclusions}

Cattle produced a severe effect on the shoreline vegetation of small ponds in south Texas. The Longtom Community and the Knotgrass-Smartweed Community, the most permanent and established of the shoreline communities, were impacted most by cattle. The more temporary Transition Community was not greatly affected by cattle, particularly on the large tanks; the Aquatic Community was least affected by cattle. Percentage foliar cover and vegetation height were decreased by grazing over the 9-month sampling period.

The effects of grazing the shoreline vegetation increased with increasing animal pressure (m shoreline/AUM). Animal impact for all communities except the Aquatic Community was greatest at SUC tank, which had four times the animal pressure of the LLP and LUC tanks. This was most evident for the Transition Community, which withstood grazing at the large tanks but was severely disturbed at the small SUC tank.

Some regeneration of vegetation was evident following the grazing rest periods in the 4-pasture, deferred-rotation system. Percentage foliar cover of grasses (mostly longtom) in the Longtom Community was not reduced as greatly during the fall and winter at LLP tank as at LUC tank, mainly because a rest period occurred from late summer to mid-winter for LLP tank.

Rest periods should coincide with the beginning of the growing season, which was not the case in this study. However, the rest periods that occurred on these pastures did coincide with the latter part of the growing season, which is greater than 300 days in south Texas, but the vegetation response was minimal.

The effect of cattle on shoreline vegetation may not benefit waterfowl. The Knotgrass-Smartweed Community, a source of smartweed seeds for ducks and nesting habitat for various marshbirds, was disturbed by cattle, and wildlife nesting value diminished. However, cattle had no significant effect on the Aquatic Community, the site of duck food plants such as southern naiad and duckweed, regardless of tank. Thus, positive values of grazing on shoreline vegetation of south Texas stock ponds in terms of waterfowl or other nesting marsh birds were few.

Fencing can be used to prevent disturbances by cattle to the shoreline vegetation. Either total or rotational fencing of ponds within a given pasture would benefit waterfowl habitat. Partially fenced tanks should have the deepest section of the ponds left open to cattle and shallow areas protected. This approach allows cattle access to water, even in the dry seasons, and protects the most potentially productive areas for wildlife. Gravelling of access areas would reduce the incidence of livestock bogging down.

Overall, the effects of cattle on the shoreline vegetation of small ponds in south Texas are a function of site, animal pressure, zonation of the vegetation, and the resistance to grazing of the plants growing in these zones.

Finally, the effects of cattle on shoreline vegetation were generally considered detrimental to wildlife habitat on small ponds studied in south Texas. Only in limited instances was grazing of value to waterfowl in this area; however, these effects can be managed so that these small bodies of water can have simultaneous livestock watering and wildlife habitat values.

\section{Literature Cited}

Berg, P.F. 1956. A study of waterfowl broods in eastern Montana with special references to movements and the relationship of reservoir fencing to production. J. Wildl. Manage. 20: 253-262.

Bolen, E.G. 1967. The ecology of the black-bellied tree duck in southern Texas. Utah State Univ., Ph.D. Thesis, Logan. 138 p.

Bolen, E.G., and B.J. Forsyth. 1967. Foods of the black-bellied whistling duck in south Texas. Wilson Bull. 79: 43-49.

Bue, I.A., L. Blankenship, and W.H. Marshall. 1952. The relationship of grazing practices to waterfowl brecding populations and production on stock ponds in western South Dakota. Trans. N. Wildl. Conf. 17: 396414.

Chabreck, R.H. 1968. The relation of cattle and cattlc grazing to marsh wildlife and plants in Louisiana. Proc. Southeastern Ass. Game and Fish Comm. 22: 55-58.

Drawe, D.L. A.D. Chamrad, and T.W. Box. 1978. Plant communities of the Welder Wildlife Refuge. Contrib. 5. Series B. Revised. Welder Wildl. Found. Sinton, Texas $38 \mathrm{p}$.

Durham, A.J., and M.M. Kothmann. 1977. Forage availability and cattle diets on the Texas coastal prairie. J. Range Manage. 30: 103-106.

Gjersing, F.M. 1975. Waterfowl production in relation to rest-rotation grazing. J. Range Manage. 28: 37-42.

Gould, F.W., and T.W. Box. 1965. Grasses of the Texas coastal bend. Texas A\&M Univ. Press, College Station. 186 p.

Hamor, W.H., H.G. Uhlig, and L.V. Compton. 1968. Ponds and marshes for wildl. ducks on farms and ranches in the northern plains. U.S. Dep. Agr. Farmers Bull. 2234. 16 p.

Hoffman, G.R., and L.D. Stanley. 1978. Effects of cattle grazing on shore vegetation of fluctuating water level reservoirs. J. Range Manage. 31: 412-416.

Jolly, C.M. 1954. The theory of sampling. p. 8-18 In: D. Brown, ed. Methods of Sampling and Measuring Vegetation. Bull. 42., Bureau 
Pastures Field Crops. Hurley, Berks., England

Jones, F.B. 1975. Flora of the Texas coastal bend. Welder Wildl. Found. Cont. B-6, Mission Press, Corpus Christi. 262 p.

Keith, L.B. 1961. A study of waterfowl ecology on small impoundments in southeastern Alberta. Wildl. Monogr. 6. 88 p.

Kirsh, L.M. 1969. Waterfowl production in relation to grazing. J. Wildl. Manage. 33: 821-828.

Lokemoen, J.T. 1973. Waterfowl production on stockwatering ponds in the northern plains. J. Range Manage. 26: 179-184.

Mundinger, J.A. 1976. Waterfowl responses to rest-rotation grazing. J. Wildl. Managc. 40: 60-68.
Robel, R.J. 1961. Water depth and turbidity in relation to growth of sago pondweed. J. Wildl. Manage. 25: 436-438.

Scifres, C.J., and J.L. Mutz. 1975. Secondary succession following extended inundation of the Texas Coastal rangeland. J. Range Manage. 28: $279-282$.

Singleton, J.R. 1965. Waterfowl habitat management in Texas. Texas Parks and Wildlife Dept. Bull. 47. Austin, Texas 68 p.

Steele, R.G.D., and J.H. Torrie. 1960. Principles and Procedures of Statistics. McGraw-Hill Book Co. Inc., New York. 481 p.

Valentine, J.M. 1969. Grazing on the Delta Refuge. Fish and Wildl. Serv., U.S. Dept. Interior. Layfayette, Louisiana. Final Report. 34 p. 